\title{
The role of the corporate HR function in global talent management
}

\author{
Elaine Farndale ${ }^{\mathrm{a}, *}$, Hugh Scullion ${ }^{\mathrm{b}, 1}$, Paul Sparrow ${ }^{\mathrm{c}, 2}$ \\ a Department of Human Resource Studies, Tilburg University, PO Box 90153, 5000 LE Tilburg, The Netherlands \\ ${ }^{\mathrm{b}}$ National University of Ireland, Department of Management, J.E. Cairnes Graduate School of Business E Public Policy, University Road, Galway, Ireland \\ ${ }^{\mathrm{c}}$ Lancaster University Management School, Bailrigg, Lancaster LA1 4YX, UK
}

\section{A R T I C L E I N F O}

\section{Keywords:}

Corporate HR function

Global talent management

Multinational corporations

\begin{abstract}
A B S T R A C T
We currently know little of the role of the corporate human resource (HR) function in multinational corporations regarding global talent management (GTM). GTM is explored here from two perspectives: increasing global competition for talent, and new forms of international mobility. The first considers the mechanisms of GTM, and the second, individual willingness to be mobile, especially in emerging markets, and the organizational capability needed to manage this talent. New corporate HR roles are identified which show how these issues might be addressed. We then advance our understanding of GTM theory and practice by considering the major future challenges facing corporate HR.
\end{abstract}

(C) 2009 Elsevier Inc. All rights reserved.

\section{Introduction}

It has been argued that the more rapid pace of internationalization and globalization leads to a more strategic role for Human Resource Management (HRM) (Novicevic \& Harvey, 2001; Scullion \& Starkey, 2000). While there have been some attempts to integrate international corporate strategy and human resource strategy (see, for example: Taylor, Beechler, \& Napier, 1996), the role of the corporate human resource (HR) function has until recently been relatively neglected in the international HRM literature, particularly in the context of the multinational corporation (MNC) and its attempts to manage talent on a global scale.

The issue of global talent management (GTM) has become an important area for research for a number of key reasons. Competition between employers has become more generic and has shifted from the country level to the regional and global levels (Ashton \& Morton, 2005; Sparrow, Brewster, \& Harris, 2004). This competition can be broken down further into two primary drivers:

1. Supply factors: A number of factors have increased the level of international mobility and opportunity for new forms of mobility, such as: the volume of migration and the shift towards skills-related immigration systems (Salt \& Millar, 2006;

\footnotetext{
* Corresponding author. Tel.: +31 134662371.

E-mail addresses: farndale@uvt.nl (E. Farndale), hugh.scullion@nuigalway.ie (H. Scullion), p.sparrow@lancaster.ac.uk (P. Sparrow).

1 Tel.: +35391 493079; Fax: +35391494510.

2 Tel.: +44 1524 593049; Fax: +44 1524381454.
}

Sparrow et al., 2004); and the globalization of a number of professional labor markets, such as healthcare and information technology (Clark, Stewart, \& Clark, 2006).

2. Demand factors: An increase in demand for: skilled expatriates to help build emerging international markets, even as the world economy is in general decline; temporary and short-term access to specialized talent to assist the execution of overseas projects and to develop emerging markets; and the need for highly mobile elites of management to perform boundary-spanning roles to help build social networks and facilitate the exchange of knowledge necessary to support globalization.

While companies are facing significant talent management challenges in several regions of the world, such as Europe and North America, the challenges are most acute for young professionals and new managers in the emerging markets such as the BRIC economies of Brazil, Russia, India, China and the economies of Central and Eastern Europe (Bhatnagar, 2007). The need for effective talent management strategies and practices that work in emerging markets is increasingly recognized by top MNC managers yet there has been little systematic research of talent management in these markets (Bhatnagar, 2007; Sparrow \& Budhwar, 1997).

There is evidence of a number of constraints that limit the effectiveness of responses to these pressures. For example, in many leading European firms, shortages of international management talent have been shown to be a significant constraint on the successful implementation of global strategies (Scullion \& Brewster, 2001). It is argued, in particular, that a shortage of leadership talent is a major obstacle many companies face as they seek to operate on a global scale. The rhetoric of maximizing the 
talent of individual employees as a unique source of competitive advantage has been a central element of strategic HR policy in recent years (Frank \& Taylor, 2004; Lewis \& Heckman, 2006). However, the extent to which organizations effectively manage their talent in this respect often fails to live up to the hype (Cappelli, 2008).

This globalization of talent management brings with it a requirement to create new HRM tools, methods and processes to provide the necessary co-ordination systems to support global integration (Kim, Park, \& Prescott, 2003). This has led to an expansion of the territory that might legitimately be considered part of a GTM system into marketing-driven concerns such as market-mapping and employer-branding (Sparrow, 2007). This also implies new roles for the Corporate HR (CHR) function: in addition to the well known strategic roles for HR laid down by Ulrich and Brockbank (2005), the multinational context requires a more nuanced approach which considers additional international pressures (Farndale et al., 2010). Here we focus our discussion on four core roles for CHR derived from the extant literature (champion of processes, guardian of culture, network leadership and intelligence, and managers of internal receptivity) and explore how these roles support GTM in MNCs. These four roles are summarized in Fig. 1, showing each role's unique activities and their interconnections. These roles will be discussed in detail in light of GTM developments.

Despite these developments, and a decade of debate around the importance of talent management for success in the increasingly competitive business environment (Michaels, Handfield-Jones, \& Axelrod, 2001; Sparrow \& Balain, 2008), the concept is still lacking in definition and theoretical development, particularly in the global context. Clearly, it is necessary to examine and clarify what is implied by GTM in its current context. In this paper we seek to examine the challenges faced by the CHR function in managing talent on a global basis and identify the main drivers of GTM, paying particular attention to the rapidly growing emerging markets. The paper reviews the research on the issues MNCs face in the context of two key challenges: global competitive pressures for talent and new forms of international mobility. We use these analyses to identify and discuss the key issues which need to be addressed to advance our understanding of the theory and practice of GTM and the implications for CHR. First, however, we start our discussion by looking at current definitions of GTM.

\section{A definition of global talent management}

Although the notion of talent management has been with us since the 1990s, and presented as a 'war' since the first McKinsey War for Talent survey of 1997, MNCs now face a new challenge: they are increasingly coordinating their talent pipelines on a global basis, leading to this notion of global talent management. Collings and Scullion (2008: 102) define GTM as "the strategic integration of resourcing and development at the international level which involves the proactive identification and development and strategic deployment of high-performing and high-potential strategic employees on a global scale". We might add also to this definition the importance of retention of these high-value employees, as seen in particular in the emerging markets mentioned previously.

In the current economic climate, it may no longer be appropriate to talk about a 'war' for talent. For example, unemployment in East Asia (including China) is expected to rise for the first time in five years from its 2008 rate of $3.8 \%$ to up to $5.5 \%$ by the end of 2009; in South Asia (including India), unemployment has already been rising to its 2008 rate of $5.4 \%$ and is predicted to either remain stable or increase to up to $6.2 \%$ over the next year (ILO, 2009). However, more people available on the labor market does not necessarily mean that employers are able to find the level of skilled managers and professionals they are seeking. For example, Teagarden, Meyer, and Jones (2008) still emphasize the growing scarcity of high-level knowledge talent in these countries. Although the war for talent may no longer be appropriate terminology, the demand for talent in practice certainly remains significant (Lane \& Pollner, 2008).

\section{Challenges faced by the corporate HR function in GTM}

From a CHR perspective, firms are facing a number of challenges in managing talent on a global basis with regard to the two key challenges: global competition, and new forms of international mobility.

\subsection{Global competition}

There is growing evidence of increasing global competition for highly skilled talent, particularly amongst MNCs, and the
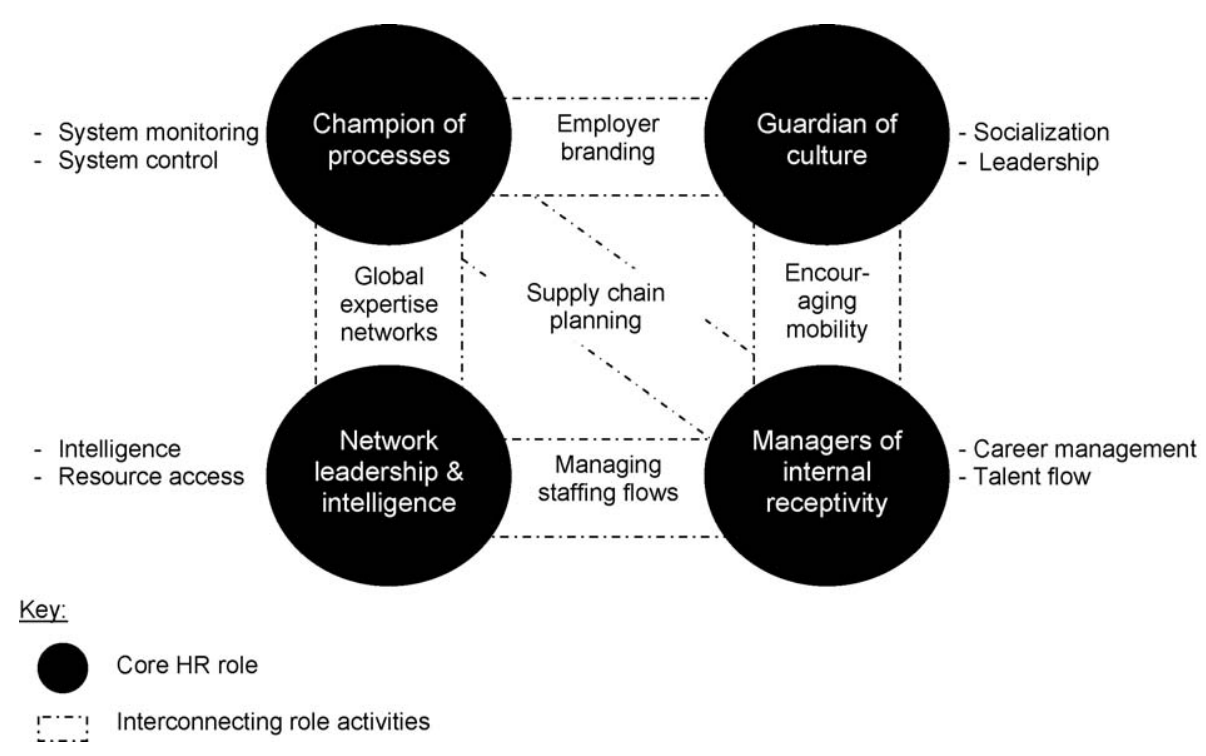

Fig. 1. Corporate HR roles in global talent management. 
emergence of a common global talent pool being shared by all the large organizations. This creates three issues:

1. In order to remain competitive, organizations are demanding increasingly high skill levels amongst their staff, and are becoming more specific about the qualities that really differentiate effective international managers (Dickmann, Sparrow, \& Brewster, 2008).

2. The supply of sufficiently educated senior staff is not meeting this demand. This has been noted in the U.S.A. (Cappelli, 2008), however it is also a growing problem in transitional and developing economies, such as China and India (Doh, Stumpf, Tymon, \& Haid, 2008; Ma \& Trigo, 2008; Teagarden et al., 2008). Organizations are broadening their internal search to wider pools of labor (Boussebaa \& Morgan, 2008).

3. In addition to broadening the internal search criteria, organizations are also integrating and extending their talent pipelines into much more forward planning activity (recruiting ahead of the curve), which means that issues such as market-mapping and employer-branding to assist in the attraction and retention of high-performing employees have become increasingly high on the corporate agenda.

Our argument that the type of talent necessary in an international context is becoming ever more specific rests on the following observations. Recent research suggests a need for managers with distinctive competencies and a desire to manage in culturally and geographically distant countries (Bjorkman \& Xiucheng, 2002; Li \& Scullion, 2006). Questions about the nature of these distinctive competencies have led to debate about what exactly it is that GTM systems must manage. To deliver effective global business processes, products or services, global managers need several forms of capital. Attention has been drawn to the need for: cognitive capital - the possession of effective mental models of how knowledge needs to be shared across the globalizing organization (Murtha, Lenway, \& Bagozzi, 1998); social capital necessary connections to be able to perform boundary-spanning roles (Kostova \& Roth, 2003); political capital - the legitimacy necessary to be confirmed as talent (Harvey \& Novicevic, 2004); and human capital - the competencies necessary to operate in cross-cultural contexts (Earley \& Mosakowski, 2004).

There is therefore considerable competition between MNCs for the small number of global managers who possess such complex capital and the in-depth knowledge of how to do business successfully in specific countries. Perhaps reflecting this, much of the literature on GTM has in practice analyzed global staffing by focusing only on the recruitment to senior positions in headquarters or subsidiaries (i.e. the resourcing of senior global managers such as directors or expatriates) with attention being directed at whether the pattern of such appointments is ethnocentric, polycentric, regiocentric or geocentric ( $c f$. Perlmutter, 1969). GTM has therefore concentrated on the international transfer of expatriates or inpatriates (Collings, Scullion, \& Dowling, 2009; Harzing \& Van Ruysseveldt, 2004; Torbiörn, 2005).

We argue that such competition is in turn leading to innovation in practice, and these innovations demonstrate the need to go beyond HR planning for global assignments and to focus on broader mechanisms of talent identification, development, deployment, retention, and succession planning. As a consequence, it is now debatable (1) which populations need to be managed under the auspices of international talent systems (Briscoe, Schuler, \& Claus, 2008; Mayrhofer, Sparrow, \& Zimmermann, 2008), (2) what form talent management is actually taking (i.e. which processes it encompasses) (CIPD, 2007), and (3) how the HR function is involved and whether it is a planned or reactive process (Cappelli, 2008).
Exploring the first debate, recent research suggests there are now a wide range of international assignment options ranging from the traditional expatriate assignment (which usually involves the relocation of the expatriate and their family) to the growing number of more flexible forms of global staffing such as short-term assignments, international commuter assignments, frequent business commuters, self-initiated movers, immigrants, global project members, and virtual team members (Collings, Scullion, \& Morley, 2007). Global staffing practices are also related to the stage of internationalization and the evolution of the international strategy (Scullion \& Collings, 2006). In the early phases of internationalization, firms will tend to place more emphasis on expatriates to establish control in the foreign markets. As international markets expand and regional/global strategies are developed, there will be greater use of alternative forms of international assignments. While researchers have highlighted the absence of empirical data about the utilization of alternative forms of assignment (Mayrhofer et al., 2008), it can be argued that rapidly changing world business circumstances mean that more flexible forms of global staffing will be increasingly used as alternatives to traditional expatriate assignments. There is therefore an argument that GTM should not just be focusing on the high-performers and high-potentials, but should have a broader remit across different levels of staff.

Secondly, at least until the onset of the current global economic crisis, the opportunities for the highly skilled, high-performing strategic employees to move between the top players in the field were rapidly increasing. Issues of employee engagement, loyalty and retention have therefore also been taking center stage (GMAC, 2008). Each different strategic employee type has a different profile (e.g., younger/older, at different points on the career path, more valued for specialist skills than management skills), which may require a nuanced approach to talent management strategies. Unilever is a case in point here. It identifies high-performers separate from high-potentials. Unilever then rewards them with additional salary rather than a promotion, reducing the drive to move to the next management grade purely for salary purposes (research interview, Unilever, HR Director, 2004).

Thirdly, globalization creates the need for new tools, processes, and metrics for GTM. These in turn require cross-functional integration in order to provide the necessary co-ordination systems to support global integration (Kim et al., 2003). Higgs, Papper, and Carr (2000) adopted a systems approach to strategic HRM to show that in response to competitive resourcing pressures both the horizontal alignment (between sub-HR activities) and vertical alignment (to internal contextual factors such as vision, values, brand or culture), have broadened, such that organizations now include a much wider range of activity under the umbrella of selection. Sparrow (2007) found that developments in employerbranding strategies were a good example of this: in Barclaycard International the globalization of international resourcing activity required aligned developments in expatriate management, the process of creating and sourcing new in-country operations, talent management and mapping activity, and the role of HR business partners in enabling these activities. The boundaries between subfunctions such as international recruitment, development and rewards became opaque in the pursuit of global talent strategies.

\subsection{New forms of international mobility and the emerging markets}

Recent discussion of talent issues in China and India exemplifies the second key challenge (Doh et al., 2008; Teagarden et al., 2008). While China had a pool of around ten million young professional graduates with work experience, a report published by the ChinaBritain Business Council (Malila, 2007) showed that less than $10 \%$ would have the necessary language and interpersonal competen- 
cies to work for MNCs in China. A similar problem exists for MNCs seeking to recruit graduates in India. The retention of knowledge workers in these emerging markets is a major challenge for MNCs and it has been suggested that in India annual turnover rates in some key sectors such as information technology and business process outsourcing can reach as high as $45 \%$ (Bhatnagar, 2007).

In a series of interviews with MNCs in China, talent was by far the most consistently and frequently cited factor that would critically affect business success (Yeung, Warner, \& Rowley, 2008). This looming shortage of home-grown talent is said to arise due to few university graduates having the necessary skills for the growing services sector (including little practical experience and still poor levels of English) (Malila, 2007), and a lack of employee mobility between provinces and the few major commercial centers (Farrell \& Grant, 2005). The sources of management talent, such as management training programs and MNCs producing their own managers, are thus unable to deliver sufficient supply (Dickel \& Watkins, 2008). Similarly, localization strategies to develop local managers either fail or take much longer than anticipated to achieve results (Evans, Pucik, \& Barsoux, 2002). To ensure the supply of the required talent, organizations therefore seek to influence the formation of skills through involvement in education systems and syllabi.

Increasing supply of more job-ready talent however creates other issues. In India, the supply of English-speaking, highly educated graduates is perhaps becoming less restricted. However, young ambitious workers are demanding immediate rewards. This is a result of the earlier talent shortage which meant that individuals could demand almost anything they wanted due to their scarce skills. Today supply is increasing and so the immediate promotions and high salary increases are less of a feature in the marketplace, although still expected by employees. Research in this area is currently lacking. From a practitioner perspective, Hamm (2008) suggests that India may be the blueprint for other emerging nations in the way in which this talent shortage has played out. The key focus for firms now is on exploring how to improve employee engagement and retention, rather than sourcing challenges.

Such developments in the emerging markets create two major issues:

1. changes in the preparedness of individuals to be mobile, both at the individual level, and at the level of the relative differences between predominantly internal or external labor markets in different national contexts, and

2. silo mentalities rather than global approaches to managing talent across businesses and countries.

Preparedness of talent to move to the new strategic markets where they are most needed cannot be guaranteed. Due to the intense competition for scarce highly skilled senior staff, these employees are also able to be more selective in the assignments they choose to accept. Mobility across international borders, and particularly to higher risk locations such as Africa or China, is proving increasingly difficult to achieve (Yeung et al., 2008). In the Global Relocation Services survey (GMAC, 2008) three countries have emerged as the fastest growing new international assignment destinations: China, India and Russia. These three countries also present the highest level of assignment difficulty both for project managers and for expatriates: $21 \%$ of firms reported China as having the highest assignment failure rates. Although a full exploration of the many varied reasons behind this failure is outside the scope of this paper, typical issues include immigration formalities, tax laws, language and cultural differences, and the salary differential experienced by employees arriving from high cost locations (GMAC, 2008).
Constraints to mobility have led organizations to draw upon new sources of talent. One well documented source includes selfinitiated movers (Tharenou, 2003). Recent research also suggests that Third Country Nationals (TCN) - individuals of other nationalities hired by an MNC to operate in a host country, but whose nationality is neither that of the host country nor the country-of-ownership of the MNC - may be growing in importance. TNCs have become a source of talent for MNCs in monitoring foreign subsidiaries, particularly in the context of standardized and formalized managerial policies and practices and incentive schemes (Harvey \& Novicevic, 2004). For example, one clothing manufacturer, Adidas, now utilizes an international external hire approach (TCNs being recruited into the Corporate HQ) to such an extent that more than half of the people receiving international mobility benefits in its HQ are this form of hire (research interview). These are generally self-initiated movers. The organization has a target of further increasing the number of international external hires by $20 \%$ as part of a strategy to build its employer brand. This is particularly relevant in the context of recent debates on the cost and value of traditional expatriate assignments, and concerns over the supply of global managers (Scullion, Collings, \& Gunnigle, 2007). The growing use of TCNs may reflect the strategy of some MNCs to increase their pool of global managers with company-specific experience in order to find staffing solutions for international assignments (Collings, Morley, \& Gunnigle, 2008).

Host country nationals (HCNs) with experience in other MNCs in the host country also represent an important source of talent and while these managers may not have company-specific experience, the know-how, networks and knowledge gained in other MNCs may be usefully transferred to the subsidiary operation (Collings et al., 2008; Sparrow et al., 2004). While offering a good potential source of management talent to MNCs in subsidiary operations, the problems of retention may be more difficult due to the competition between MNCs for experienced staff (Collings \& Scullion, 2009).

Another strategy is to access already-acculturated talent: expatriates from developing countries who have had the opportunity to work in developed countries. Some MNCs have underestimated the value of the inpatriation of HCNs and TCNs into Corporate HQ as a means of increasing the pool of managers available for international assignments (Harvey, Speier, \& Novicevic, 1999). Inpatriation also helps socialize HCN and TCN managers into the corporate culture. Research suggests that inpatriates are a rapidly increasing source of international management talent (Reiche, 2006; Scullion \& Collings, 2006) and several key drivers of this development have been identified: the desire to create a global core competency or a diversity of strategic perspectives among the top management team (Harvey, Speier, \& Novicevic, 2001); the rapid emergence of developing markets which are less likely to be accepted by traditional expatriate pools; and the growing need to provide career opportunities for high-potential employees.

All of these sourcing options are increasingly important for MNCs operating in environments where cost pressures are particularly acute. These agencies pose limitations on traditional international assignments (Scullion \& Collings, 2006).

A second issue raised by the new forms of international mobility is the ability of organizations to provide 'joined-up' talent strategies. For example, silo mentalities can emerge in large, complex MNC structures. Defensive behavior within business or geographic regions can result in less efficient flows across the firm as a whole, hence reducing the effectiveness of any GTM strategy. Research suggests this problem can be particularly acute in highly decentralized MNCs where central systems of coordination and control are weakly developed (Scullion \& Starkey, 2000). In 
addition to silo mentalities, research shows that failure by many MNCs to adopt a strategic approach to repatriation impacts adversely on the supply of global managers, and that many MNCs continue to adopt ad hoc approaches (Scullion \& Brewster, 2001). Many firms do not use the repatriation process to build on the employee's knowledge gained from the assignment, and often international assignments do not result in positive career progression (Dowling, Festing, \& Engle, 2008: 192). Hence many international assignees leave the firm on their return from abroad and managers are increasingly reluctant to accept international assignments due to the negative repatriate experiences of colleagues. In addition many expatriate managers continue to experience the expatriation process as falling far short of expectations (Stroh, Gregerson, \& Black, 2000). Research confirms the need for MNCs to develop a more strategic approach to repatriation in order to retain high-value talent and to encourage managers to accept international assignments (Evans et al., 2002). These issues are picked up further when we consider the implications this has for the role of the CHR function.

\section{Changing role of the corporate HR function in MNCs}

Having examined some of the key challenges and possible responses to managing talent on a global basis, we now move on to examine the related role of the CHR function. Although little has yet been explored regarding CHR roles in MNCs, there are some initial studies emerging on what these may be. Empirical research on UK MNCs has highlighted a considerable variation in the roles of the CHR function in different types of international firms (Scullion \& Starkey, 2000). In centralized/global firms the CHR function undertook a wide range of activities and the key roles were management development, succession planning, career planning, strategic staffing, top management rewards and managing the mobility of international managers. In these firms the growing need for coordination and integration of international activities required greater central control over the mobility of top managers, expatriates and high-potential staff. In highly decentralized firms, on the other hand, who tended to pursue more of a multidomestic international strategy, the CHR executives focused mainly on management development and succession planning for senior executives. One common theme such studies have is that they emphasize the key role of CHR in GTM for the top talent across the company (Brewster, Sparrow, \& Harris, 2005; Farndale et al., 2010; Kelly, 2001; Novicevic \& Harvey, 2001). Particularly the demand factors noted have created an emerging agenda for CHR to develop core management competencies by focusing on the talent management issues associated with senior management development, succession planning and developing a cadre of global managers (Evans et al., 2002; Scullion \& Starkey, 2000; Sparrow, 2007).

Looking in more detail at the implementation of corporate HRM policies throughout overseas subsidiaries, CHR can play a significant role in coordination and monitoring (Kelly, 2001). Based on this and our review of GTM, we identify four important roles (see also Fig. 1).

\subsection{Champions of processes}

Research at the major drinks multinational Diageo showed the importance of building the commitment of top management, providing coaching and training for managers, calibrating and equalizing talent across markets, enabling and aligning $\mathrm{HR}$ information systems, and monitoring talent management processes (Sparrow et al., 2004). Particularly the latter point highlights CHR's role as “champions of processes” (Evans et al., 2002: 472). Given the global competition context, the demand for higher skill levels amongst staff has lead to the need to specify more closely the sorts of capital (human, social, intellectual and political) that constitute 'talent'. Competitive forces are also requiring organizations to take control of the skills supply-chain through the use of more forward planning activity such as strategic workforce planning, market-mapping and employer-branding (Sparrow \& Balain, 2008). These drivers have raised the need for better horizontal coordination of tools, techniques and processes for talent management across internal functions. This in turn requires both effective management of global expertise networks and a designated champion of processes role to monitor the global implementation of a talent management strategy and related tools.

\subsection{Guardians of culture}

HR has a social responsibility to ensure the organization is sensitive and equipped to deal with global challenges. Social context theory explains how corporate culture represents an organizational social environment which influences the establishment of an HRM system (Ferris, Hochwarter, Buckley, HarrellCook, \& Frink, 1999). It is also a form of social control which encourages behaviors and attitudes appropriate for an organization's members to display (O'Reilly \& Chatman, 1996), for example, international mobility. This creates a role for CHR as guardian of culture (Brewster et al., 2005), overseeing the implementation of global values and systems when it comes to developing a talent management culture and employer brand across the organization (Ulrich \& Smallwood, 2007). The role of CHR in MNCs has also been found to encourage a culture of trust and motivation to work together, through the design of appropriate practices, processes and structures (Gratton, 2005). This gives CHR the opportunity to focus on 'talentship'-better human capital decision-making (Boudreau \& Ramstad, 2006). CHR can therefore play a key role in encouraging a 'joined-up' approach to GTM across the whole organization; the guardian of culture role could be key to ensure the right approach to GTM across the organization, creating a climate in which people feel encouraged to be mobile but valued for their difference. These are crucial steps in breaking down the silo mentality that exists within firms today within business and geographic regions (Gratton, 2005).

\subsection{Network leadership and intelligence}

Network leadership is a term used by Evans et al. (2002: 471) indicating HR should have: an awareness of leading edge trends and developments in the internal and external labor market, the ability to mobilize the appropriate human resources, and a sense of timing and context (sensitivity to what is going on at both local and global levels). Firstly, although 'leadership' may not be the most appropriate terminology here given the frequently cited limited powerbase of the HR function (Farndale, 2005), the importance of being well-networked is crucial. This includes being aware of events both inside and outside the organization, but also for CHR to take on the role of facilitating collaboration across the organization; HR's role in building social capital beyond organizational boundaries to encourage cooperation across the company and improve firm success has been recognized (Gratton, 2005; Lengnick-Hall \& Lengnick-Hall, 2006; Mäkelä, 2007; Taylor, 2007). Mäkelä's (2007) study of expatriates has shown how social capital becomes important for global talent-their relationships are richer, more trustful and longer term than more arm's-length cross-border relationships, and these properties create more opportunities for knowledge sharing, and have a multiplying effect by spreading ties more effectively across new units. Lengthened participation in the assignment unit typically leads to a higher level of shared cognitive ground, effectively facilitating 
knowledge. For Taylor (2007: 337) a pressing need now is then “...the identification, development and retention of managers, particularly those crossing geographic and cultural boundaries (high-value boundary spanners or HVBS), who can successfully develop social capital in multiple cultural settings". She highlights the need for IHRM functions to manage both structural social capital (the configuration, density and strength of relationships between HVBS's) and cognitive social capital (shared goals and shared culture i.e. language, codes and narratives). She notes that the competencies needed to do this are little understood.

Secondly, we would add the dimension of intelligence about networks to this role. The majority of talent services (such as market intelligence, search capabilities, sourcing tools and techniques) are now distributed externally across a host of specialized or outsourced providers, or internally (within projects that have initiated new practices). We argue that taking a more proactive stance, and knowing both the talent markets and the capabilities created by different providers and practices, is a key role requirement for GTM. This creates a networking role for the HR function as a boundary spanner (Kostova \& Roth, 2003) between external providers and the organization.

\subsection{Managers of internal receptivity}

Research on sectors (such as healthcare and education) that have learned how to source international labor into domestic markets, as well as research on inpatriation, show that CHR can play an active role in the career management of international employees-encouraging mobility but also ensuring individuals are looked after in the process (in terms of the receptivity of the receiving units to manage diversity, career management, integration and work-life balance issues). The traditional male expatriate, mid-career, moving abroad possibly with family, is no longer the standard model. As more self-initiated movers and TCNs/HCNs become involved in international assignments, as well as these assignments taking different forms, a more complex but flexible approach to career management is required. CHR is ideally positioned to have the necessary overview across the organization to be able to manage this talent flow, by changing HR processes, challenging local mindsets and practices, and looking for new lower-cost forms of meeting international experience demands and skills shortages.

Despite the emergence of these four core CHR roles, there is still confusion regarding the specific role that HR professionals in particular should play in GTM processes, which places question marks over the ability of CHR professionals to manage their own destiny. Corporate HR professionals work alongside top management who has the option of outsourcing some of their activities. Although HR Directors were found to be the primary decisionmakers for outsourcing (GMAC, 2008), and can claim more insight into the risks involved in using external agencies given the complex compliance issues (such as immigration and taxes) involved in global resourcing, some practitioner evidence suggests that HR's corporate impact is still declining (Guthridge, Komm, \& Lawson, 2008). McKinsey found that the three key talent management activities carried out amongst high-performing firms are: ensuring global consistency in management processes, achieving cultural diversity, and developing global leaders (Guthridge \& Komm, 2008). However, this evidence comes from reports from practice, rather than empirical research which is lacking in this field.

As Gratton (2003: 18) highlights: "during the past decade we have fragmented the roles and responsibilities of the function [...] and this fragmentation of the HR function is causing all sorts of unintended problems. Senior managers look at the fragments and are not clear how the function as a whole adds value". Such criticism can partly be attributed to a lack of business knowledge and not being recognized as a profession (Farndale, 2005). It potentially means fewer high-performers wish to work in the function, exacerbated by this fragmentation which leads to reduced capabilities and status.

There is evidence that MNCs are putting in structural solutions to move what were previously only network linkages between International Mobility and Talent Management functions. For example, based on the 2008 Global Relocation Survey of 25 financial services firms and additional interview data from the senior international management (IM) functionaries of eight of these firms, Sparrow (2008) asked whether international mobility (or associated expatriation activity) should become a center of excellence in its own right, or whether it should report via another such center, such as talent management. The research showed that by far the most important influence on the relationship and division of responsibilities between central IM specialists, and incountry or in-business division HR partners, was the structural reporting relationship of the IM function. The solution chosen affords or denies the IM function entry into a range of HR issues also linked to international mobility. Many IM functions, by dint of history, still report into a compensation and benefits function that is responsible for the terms, conditions and financial package for expatriates. There is a trend, especially in those financial service organizations that have mature international markets, towards aligning IM under a talent management umbrella. A number of MNCs are already creating the structural solutions that will forge new talent management directorates that can manage these global mobility processes.

\section{Major challenges and constraints moving forward}

Having reviewed the drivers of approaches to GTM, and the potential impact they are having on the role of CHR in MNCs, this final section considers some major challenges and constraints facing the CHR role in the future and also suggests some areas for future research.

In this paper we have attempted to summarize the growing importance of the management of talent on a global scale. Both the supply of talent (through changing patterns of migration and the internationalization of certain labor markets), and the demand for talent are expected to continue to increase despite a downturn in economic forecasts (Teagarden et al., 2008). However, the demand criteria do not appear to match the supply characteristics. Today, MNCs increasingly demand highly skilled, highly flexible, mobile employees who can deliver the desired results, operating sometimes in difficult circumstances (Roberts, Kossek, \& Ozekei, 1998). According to practice, this is particularly true of the conditions in the emerging markets such as China and (perhaps now to a lesser extent) India (Lane \& Pollner, 2008). This challenge requires an innovative response from the MNC as a whole, and in particular from the CHR function. New tools, processes and coordination capabilities are required to focus in particular on the sourcing, retention and career planning of the key talent across the corporation. This is a major challenge and opportunity for CHR managers seeking to redefine their role in a context of downsizing, restructuring and outsourcing. If CHR fails to achieve this, this can have major consequences for the implementation of corporate strategy, and for achieving the levels of competitive advantage which a firm's talent can create. As yet, there is little evidence that MNCs are indeed stepping up to this challenge (Cappelli, 2008).

We have also attempted to identify here four specific roles for CHR in GTM: champions of process, guardians of culture, network leadership and intelligence, and managers of internal receptivity (see Fig. 1). The ultimate aim of MNCs is to build a core competence of being able to transfer capability across multiple countries, which 
involves monitoring the implementation of relevant policies and practices, encouraging an appropriate corporate culture, establishing the necessary networks, and ensuring all parts of the organization are sensitive to the needs of international staff. Based on trends of increasing local sourcing as described earlier, this requires a shift to a capability-driven perspective (Sparrow et al., 2004) which entails a focus across the firm to participate in mutual sharing of talent and engage in joined-up thinking and action with regard to GTM. This implies a role for both CHR and senior leadership. In general, we are seeing more centralization of talent management strategies, particularly at regional if not global level (Collings et al., 2008). However, the importance of informal control in decentralized structures has also been shown to be crucial (Scullion \& Starkey, 2000). This informal approach is described as more difficult to achieve but highly effective. Future research could focus in particular on the challenges and value of balancing both informal and formal forms of control over GTM in different types of MNC settings.

Given the importance of these issues, it is perhaps surprising that there is little evidence or discussion about how the CHR function measures success for GTM in different contexts. We are forced to rely on evidence from practice. Where MNCs appear to fail to develop appropriate talent management strategies for recruiting and managing international talent, they have been shown to be less likely to succeed in international business (Guthridge \& Komm, 2008). To support the case for closer measurement of GTM, McKinsey report that more activity in GTM activities across their ten dimensions was highly correlated with higher profit per employee (Guthridge \& Komm, 2008). Further empirical research is needed in particular into how MNCs balance the short-term needs of operating businesses against the long-term strategic goals of GTM and alignment with corporate strategy and business models.

There is also an urgent need for more empirical research on GTM strategies and practices in the emerging markets due to the rapid growth of these markets and the dearth of empirical research in this area. Research in practice suggests that talent management challenges are particularly acute here (Lane \& Pollner, 2008). In addition, there is a growing need to investigate empirically the relevance and applicability of constructs to important organizational issues and problems in non-western cultures (Luthans, Zhu, \& Avolio, 2006). For example, Sparrow and Budhwar (1997) argue that in some emerging markets such as India the work culture there requires a distinctive style of transformational leadership and that talent management tools which promote engagement and retention have a strong interpersonal and spiritual orientation.

GTM is a very broad concept as can be seen from the discussion presented here, and is being applied in many different ways across different organization contexts. We have highlighted here some ways in which CHR can contribute to successful GTM given these many challenges. However, there are many issues still left unexplored. Future research could consider issues around worklife balance and dual-career couples for the global transfer of employees. There is growing evidence to suggest that families are less willing to accept the disruption of personal and social lives associated with international assignments than was the case in the past (Scullion \& Brewster, 2001). Dual career issues are increasingly seen as a worldwide trend which can pose significant restrictions on the career plans of multinationals (Sparrow et al., 2004). In addition, despite the growing shortages of international management talent (Scullion \& Brewster, 2001) the evidence suggests that the participation of women in international management remains relatively low and that many women are denied opportunities to expand their career horizons through access to international careers (Adler, 2002).
Recent research suggests there is growing evidence that an MNC's corporate social responsibility (CSR) activities are becoming an increasingly important way to attract and retain high-potential and high-value employees (Macey \& Schneider, 2008). It is suggested that employees identify with a company more when they think that it is acting in a socially responsible manner and that CSR contributes to employee identification and pride in the company (Bhattacharaya, Sen, \& Korschun, 2008). We have noted the incorporation of marketing activity, such as employerbranding, into the GTM function and CHR role, but future research should also examine the links between CSR and talent management. This could be particularly fruitful in the emerging markets such as India and China which have seen the infusion of managerial practices from around the world due to the increased openness to international trade and de-regulation.

Finally, we raise some research issues relating to the implications of the current financial crisis which struck most of the world's national and regional economic systems in 2008. First, researchers will need to address wider issues such as how the organization and management of the MNC is affected by the crisis, and indeed the legitimacy of stakeholder management models found in firms in the Anglo-Saxon world may be increasingly questioned. A number of issues also relate specifically to the future role of the CHR function: Does the crisis represent an opportunity for CHR to demonstrate the contribution of HR to the business strategy by helping to develop managers with the capacity to escape the conventions of the past and build entirely new industries (Hamel \& Prahalad, 1996)? Can CHR help the company to line up its best talent to take advantage of the strategic new opportunities which will arise in the future? Other key research questions include: What impact will the crisis have on the demand and supply for talent and on forms of international mobility? How, in general, will patterns of global staffing be affected by the global crisis?

One remaining key issue would be to examine the extent to which the crisis has impacted on the opportunities for highpotential knowledge workers and managers to move between leading MNCs. Future research should examine how strategies of employee retention and engagement operate in the very different context of the financial crisis. Further research will also be required on the how the CHR function balances the need to manage strategic HR issues with the need to respond to short-term pressures to cut costs and the growing trends towards the outsourcing of HR-the growing need to lose non-core HR activity which does not add value to the business. Finally, further research is required on the management of the HR function itself, and in particular the internationalization of the HR function, mirroring the developments in GTM.

\section{References}

Adler, N. (2002). Global managers: No longer men alone. International Journal of Human Resource Management, 13: 743-760.

Ashton, C., \& Morton, L. (2005). Managing talent for competitive advantage. Strategic HR Review, 4(5): 28-31.

Bhatnagar, J. (2007). Talent management strategy of employee engagement in Indian ITES employees: Key to retention. Employee Relations, 29: 640-663.

Bhattacharaya, C. B., Sen, S., \& Korschun, D. (2008). Using corporate social responsibility to win the war for talent. MIT Sloan Management Review, 49: 37-44.

Bjorkman, I., \& Xiucheng, F. (2002). Human resource management and the performance of western firms in China. International Journal of Human Resource Management, 1: $853-864$.

Boudreau, J. W., \& Ramstad, P. M. (2006). Talentship and HR measurement and analysis: From ROI to strategic organizational change. Human Resource Planning, 29: 25-33.

Boussebaa, M., \& Morgan, G. (2008). Managing talent across national borders: The challenges faced by an international retail group. Critical Perspectives on International Business, 4(1): 25-41.

Brewster, C., Sparrow, P. R., \& Harris, H. (2005). Towards a new model of globalizing human resource management. International Journal of Human Resource Management, 16: 953-974

Briscoe, D., Schuler, R. S., \& Claus, L. (2008). International human resource management (3rd ed.). New York, NY: Routledge. 
Cappelli, P. (2008). Talent management for the twenty-first century. Harvard Business Review, March: 74-81.

CIPD. (2007). Talent management: Research insight. London, UK: Chartered Institute of Personnel and Development.

Clark, P. F., Stewart, J. B., \& Clark, D. A. (2006). The globalization of the labor market for health-care professionals. International Labor Review, 145: 37-64.

Collings, D. G., \& Scullion, H. (2009). Global Staffing. International Journal of Human Resource Management, 20(6): 1249-1252.

Collings, D. G., \& Scullion, H. (2008). Resourcing international assignees. In M. Dickman, C. Brewster, \& P. Sparrow (Eds.), International human resource management: A European Perspective (pp. 87-106). Abingdon, UK: Routledge.

Collings, D. G., Morley, M., \& Gunnigle, P. (2008). Composing the top management team in the international subsidiary: Qualitative evidence on international staffing in US multinationals in the Republic of Ireland. Journal of World Business, 43: 197-212.

Collings, D. G., Scullion, H., \& Dowling, P. J. (2009). Global staffing: A review and thematic research agenda. International Journal of Human Resource Management, 20(6): 1253-1272.

Collings, D. G., Scullion, H., \& Morley, M. (2007). Changing patterns of global staffing in the multinational enterprise: Challenges to the conventional expatriate assignment and emerging alternatives. Journal of World Business, 42: 198-213.

Dickel, T., \& Watkins, C. (2008). To remain competitive in China's tight labor market companies must prioritize talent management-And track compensation trends. China Business Review, July-August: 20-23.

Dickmann, M., Sparrow, P. R., \& Brewster, C. (2008). International human resource management: A European Perspective. London, UK: Routledge.

Doh, J. P., Stumpf, S. A., Tymon, W., \& Haid, M. (2008). How to retain talent in India. MIT Sloan Management Review, 50(1): 6-7.

Dowling, P., Festing, M., \& Engle, A. D. (2008). International human resource management: Managing people in a multinational context (5th ed.). London, UK: Thomson Learning.

Earley, C., \& Mosakowski, E. (2004). Cultural intelligence. Harvard Business Review, October: 139-146.

Evans, P., Pucik, V., \& Barsoux, J. (2002). The global challenge. Frameworks for international human resource management. New York, NY: McGraw-Hill.

Farndale, E. (2005). HR department professionalism: A comparison between the UK and other European countries. International Journal of Human Resource Management, 16(5): 660-675.

Farndale, E., Paauwe, J., Morris, S. S., Stahl, G. K., Stiles, P., Trevor, J., et al. (2010). Context-bound configurations of corporate HR functions in multinational corporations around the globe. Human Resource Management 49(1).

Ferris, G. R., Hochwarter, W. A., Buckley, M. R., Harrell-Cook, G., \& Frink, D. D. (1999). Human resources management: Some new directions. Journal of Management, 25: 385-415.

Farrell, D., \& Grant, A. J. (2005). China's looming talent shortage. The McKinsey Quarterly 4.

Frank, F. D., \& Taylor, C. R. (2004). Talent management: Trends that will shape the future. Human Resource Planning, 27(1): 33-41.

GMAC. (2008). Global Relocation Trends. 2008 Survey Report. Woodridge, IL: GMAC Global Relocation Services.

Gratton, L. (2003). The humpty dumpty effect: A view of a fragmented HR function. People Management, 9(9): 18.

Gratton, L. (2005). Managing integration through cooperation. Human Resource Management, 44(2): 151-158.

Guthridge, M., \& Komm, A. B. (2008). Why multinationals struggle to manage talent. The McKinsey Quarterly, May: 1-5.

Guthridge, M., Komm, A. B., \& Lawson, E. (2008). Making talent a strategic priority. The McKinsey Quarterly, 1: 49-59.

Hamel, G., \& Prahalad, C. K. (1996). Competing in the new economy: Managing out of bounds. Strategic Management Journal, 17: 237-242.

Hamm, S. (2008). Young and impatient in India. BusinessWeek, January 17: http:// www.businessweek.com/magazine/content/08_04/b4068034072937.htm?chan=magazine+channel_in+depth+-+davos+special+report (accessed July 21, 2008).

Harvey, M., \& Novicevic, M. M. (2004). The development of political skill and political capital by global leaders through global assignments. International Journal of Human Resource Management, 15(7): 1173-1188.

Harvey, M. G., Speier, C., \& Novicevic, M. M. (1999). The role of inpatriation in global staffing. International Journal of Human Resource Management, 10: 459-476.

Harvey, M., Speier, C., \& Novicevic, M. M. (2001). A theory based framework for strategic global human resource staffing policies and practices. International Journal of Human Resource Management, 12: 898-915.

Harzing, A. W. K., \& Van Ruysseveldt, J. (2004). International human resource management (2nd ed.). London, UK: Sage.

Higgs, A., Papper, E., \& Carr, L. (2000). Integrating selection with other organizational processes and systems. In J. F. Kehoe (Ed.), Managing selection in changing organizations (pp. 73-122). San Francisco, CA: Jossey-Bass.

ILO. (2009). Global Employment Trends January 2009. Geneva, Switzerland: International Labor Office.

Kelly, J. (2001). The role of the personnel/HR function in multinational companies. Employee Relations, 23: 536-557.

Kim, K., Park, J.-H., \& Prescott, J. E. (2003). The global integration of business functions: A study of multinational businesses in integrated global industries. Journal of International Business Studies, 34: 327-344.

Kostova, T., \& Roth, K. (2003). Social capital in multinational corporations and a micromacro model of its formation. Academy of Management Review, 28: 297-317.

Lane, K., \& Pollner, F. (2008). How to address China's talent shortage. McKinsey Quarterly, 3: 2008
Lengnick-Hall, M. L., \& Lengnick-Hall, C. A. (2006). International Human Resource Management and Social Network/Social Capital Theory. In G. K. Stahl \& I. Bjorkman (Eds.), Handbook of Research in International Human Resource Management (pp. 475-487). Cheltenham, UK: Edward Elgar.

Li, S., \& Scullion, H. (2006). Bridging the distance: Managing cross-border knowledge holders. Asia Pacific Journal of Management, 23: 71-92.

Lewis, R. E., \& Heckman, R. J. (2006). Talent management: A critical review. Human Resource Management Review, 16(2): 139-154.

Luthans, F., Zhu, W., \& Avolio, B. J. (2006). The impact of efficacy on work attitudes across cultures. Journal of World Business, 41: 121-132.

Ma, S., \& Trigo, V. (2008). Winning the war for managerial talent in China: An empirical study. The Chinese Economy, 41(3): 34-57.

Macey, W. H., \& Schneider, B. (2008). The meaning of employee engagement. Industrial and Organizational Psychology, 1: 3-30.

Mäkelä, K. (2007). Knowledge sharing through expatriate relationships: A social capital perspective. International Studies of Management and Organization, 37: 108-125.

Malila, J. (2007). The great look forward: China's evolution. China Business Review, 34 16-19.

Mayrhofer, W., Sparrow, P. R., \& Zimmermann, A. (2008). Modern forms of international working. In M. Dickmann, C. Brewster, \& P. R. Sparrow (Eds.), International human resource management: A European perspective (pp. 219-239). London, UK: Routledge.

Michaels, E., Handfield-Jones, H., \& Axelrod, B. (2001). The war for talent. Boston, MA: Harvard Business School Press.

Murtha, T. P., Lenway, S. A., \& Bagozzi, R. P. (1998). Global mind-sets and cognitive shift in a complex multinational corporation. Strategic Management Journal, 19: 97-114.

Novicevic, M. M., \& Harvey, M. (2001). The changing role of the corporate HR function in global organizations of the twenty-first century. International Journal of Human Resource Management, 12: 1251-1268.

O'Reilly, C., \& Chatman, J. (1996). Culture as social control: Corporations, cults, and commitment. In Shaw, B., \& Cummings, L. (Eds.), Research in organizational behavior. Vol. 18 (pp.157-200). Greenwich, CT: JAI Press.

Perlmutter, H. V. (1969). The tortuous evolution of the multinational corporation. Journal of World Business, 4: 9-18.

Reiche, B. S. (2006). The inpatriate experience in multinational corporations. An exploratory case study in Germany. International Journal of Human Resource Management, 17: 1572-1590.

Roberts, K., Kossek, E. E., \& Ozekei, C. (1998). Managing the global workforce: Challenges and strategies. Academy of Management Executive, 12(4): 93-106.

Salt, J., \& Millar, J. (2006). International migration in interesting times: The case of the UK. People and Place, 14: 14-25.

Scullion, H., \& Brewster, C. (2001). Managing expatriates: Messages from Europe Journal of World Business, 36: 346-365.

Scullion, H., \& Collings, D. G. (2006). Global staffing. London, UK: Routledge.

Scullion, H., Collings, D. G., \& Gunnigle, P. (2007). International HRM in the 21st century: Emerging themes and contemporary debates. Human Resource Management Journal, 17: 309-319.

Scullion, H., \& Starkey, K. (2000). In search of the changing role of the corporate human resource function in the international firm. International Journal of Human Resource Management, 11: 1061-1081.

Sparrow, P. R. (2007). Globalization of HR at function level: Four UK-based case studies of the international recruitment and selection process. International Journal of Human Resource Management, 18: 144-166.

Sparrow, P. R. (2008). International mobility in the financial services sector: The challenge of emerging markets. GMAC Global Relocation Trends Report. London, UK: GMAC.

Sparrow, P. R., \& Balain, S. (2008). Talent proofing the organization. In C. L. Cooper \& R Burke (Eds.), The peak performing organization (pp. 108-128). London: Routledge.

Sparrow, P. R., \& Budhwar, P. S. (1997). Competition and change: Mapping the Indian HRM recipe against world-wide patterns. Journal of World Business, 32: 224-242.

Sparrow, P. R., Brewster, C., \& Harris, H. (2004). Globalizing human resource management. London, UK: Routledge.

Stroh, L. K., Gregerson, H. B., \& Black, J. S. (2000). Triumphs and tragedies: Expectations and commitments upon repatriation. International Journal of Human Resource Management, 11: 681-697.

Taylor, S. (2007). Creating social capital in MNCs: The international human resource management challenge. Human Resource Management Journal, 17: 336-354.

Taylor, S., Beechler, S., \& Napier, N. (1996). Toward an integrative model of strategic international human resource management. Academy of Management Review, 21: 959-985.

Teagarden, M. B., Meyer, J., \& Jones, D. (2008). Knowledge sharing among high-tech MNCs in China and India: Invisible barriers, best practices and next steps. Organizational Dynamics, 37(2): 190-202.

Tharenou, P. (2003). The initial development of receptivity to working abroad: Selfinitiated international work opportunities in young graduate employees. Journal of Occupational and Organizational Psychology, 76: 489-515.

Torbiörn, I. (2005). Staffing policies and practices in European MNCs: Strategic sophis tication, culture-bound policies or ad-hoc reactivity? In H. Scullion \& M. Linehan (Eds.), International human resource management: A critical text (pp. 47-68). Basingstoke, UK: Palgrave Macmillan.

Ulrich, D., \& Brockbank, W. (2005). Role call. People Management, 11: 24-28.

Ulrich, D., \& Smallwood, N. (2007). Leadership brand: Developing customer-focused leaders to drive performance and build lasting value. Boston, MA: Harvard Business School Press.

Yeung, A. K., Warner, M., \& Rowley, C. (2008). Growth and globalization: Evolution of human resource management practices in Asia. Human Resource Management, 47 $1-13$ 